\title{
ПОРІВНЯЛЬНИЙ АНАЛІЗ РЕЗУЛЬТАТІВ ЯКІСНОЇ УСПІШНОСТІ СТУДЕНТІВ ПРИ ПРОВЕДЕННІ ПІДСУМКОВОГО МОДУЛЬНОГО КОНТРОЛЮ
}

\author{
О. В. Кузьменко, С. О. Коноваленко \\ Вищий навчальний комунальний заклад Львівської обласної ради \\ «Львівський медичний коледж імені Андрея Крупинського" \\ ДВНЗ «Тернопільський державний медичний університет \\ імені І. Я. Горбачевського МОЗ Украӥни»
}

\begin{abstract}
У статті проаналізована якісна успішність студентів медичного коледжу з дисципліни «Анатомія людини» за підсумками пілотного тестового контролю як незалежного кінцевого етапу оцінювання та двохетапної системи підсумкового модульного контролю (тестування та практичні навички).
\end{abstract}

\section{COMPARATIVE ANALYSIS OF STUDENTS' ACHIEVEMENT QUALITY ON THE RESULTS OF FINAL MODULE CONTROL}

\author{
O. V. Kuzmenko, S. O. Konovalenko \\ Higher Educational Municipal Institution of Lviv Regional Council \\ "Lviv Medical College named after Andrew Krupynsky" \\ SHEI «Ternopil State Medical University by I. Ya. Horbachevsky of MPH of Ukraine»
}

The article analyzes the qualitative achivments of medical college students in the discipline of human anatomy on the results of the pilot test control, as an independent final evaluation stage and two-stage final module control system (testing and practical skills).

Вступ. У системі медично освіти Укра ни останнім часом зростає значення проведення тестування з профільних дисциплін для контролю отриманих студентами знань. Анатомія людини за обсягом та значенням $\epsilon$ одним із найбільш вагомих предметів серед теоретичних дисциплін, що вивчаються у закладах вищо медично освіти. 3 огляду на це, постає питання щодо відповідності прикінцевих результатів об'єктивним знанням студентів. 3 метою встановлення відповідності тестового контролю як єдиного критерію визначення оцінки за підсумковий модуль було проаналізовано в порівняльному аспекті результати підсумкового контролю при традиційному підході (з урахуванням тестового контролю та результатів складання практичних навичок) та одного тестового контролю як пілотно форми складання підсумкового модуля.

Основна частина. Протягом періоду навчання тестовий контроль проводився з вико-

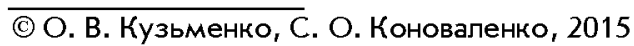

ристанням баз тестових завдань з дисципліни «Анатомія людини», рекомендованих для підготовки студентів медичних коледжів. 3 метою оптимізаці підготовки до тестування співробітниками коледжу тести були розподілені за темами відповідно до навчальних планів і розміщені в такому вигляді на інтернет-сайті Вищого навчального комунального закладу Львівсько обласно ради «Львівський медичний коледж імені Андрея Крупинського» на сторінці анатомія людини. Загальна кількість тестових завдань для студентів складає близько 800. Окрім підсумкових контролів, тестові бази використовуються при проведенні змістовних модулів (семінарських занять) та поточного контролю таким чином: студент, який показав на змістовному модулі результат тестування нижче 60,5 \% правильних відповідей отримує оцінку «незадовільно" і до наступних етапів змістовного модуля не допускається [6, 9]. У подальшому студент допускається до перескладання змістовного модуля за умов подолання означеного відсоткового бар'єра тестування. Кількість перескладань 
не обмежується в межах терміну вивчення дисципліни [8].

Наприкінці курсу вивчення дисципліни студенти складають передекзаменаційний тестовий «зріз» знань, за результатами якого можна прогнозувати підсумкову результативність при складанні екзамену [2, 4].

Наступним і завершуючим етапом вивчення дисципліни є складання студентами підсумкового модульного контролю, який проводиться у вигляді тестового контролю організованого методичним кабінетом. Це дало змогу провести незалежний завершальний етап контролю знань
[5]. Подібна практика широко використовується в медичних ВНЗ Укра ни - Тернопільському державному медичному університеті імені І. Я. Горбачевського, Запорізькому державному медичному університеті. Контроль практичних навичок студентів з дисципліни «Анатомія людини» був проведений на останньому занятті семестру та не був критерієм допуску до складання тестів [1, 3].

Нами проведений кількісний аналіз чисельності студентів за різними спеціальностями та формами навчання, який наведено в таблиці 1.

\section{Таблиця 1. Кількісний аналіз студентів за різними спеціальностями та формами навчання (2013 р., 2014 р.)}

\begin{tabular}{|c|c|c|c|c|c|}
\hline \multirow{3}{*}{ Рік } & \multirow{3}{*}{ Форма навчання } & \multicolumn{4}{|c|}{ Спеціальність } \\
\hline & & \multicolumn{2}{|c|}{ сестринська справа } & \multirow{2}{*}{$\begin{array}{c}\text { акушерська } \\
\text { справа }\end{array}$} & \multirow{2}{*}{$\begin{array}{l}\text { стоматологія } \\
\text { ортопедична }\end{array}$} \\
\hline & & $\begin{array}{c}\text { денна форма } \\
\text { навчаня }\end{array}$ & $\begin{array}{c}\text { вечірня форма } \\
\text { навчаня }\end{array}$ & & \\
\hline \multirow{2}{*}{2013} & державна & 90 & 35 & 20 & 5 \\
\hline & контрактна & 85 & 25 & 10 & 10 \\
\hline \multirow{2}{*}{2014} & державна & 90 & 35 & 16 & 5 \\
\hline & контрактна & 80 & 25 & 14 & 15 \\
\hline
\end{tabular}

Ми зіставили результати якісно успішності при двох різних формах оцінювання, що були використані у 2013 році (традиційний підхід) та у 2014 році (пілотний тестовий контроль). Результати даного зіставлення відображено у таблиці 2. Найкращі результати демонструють сту- денти державних форм навчання за спеціальністю “Сестринська справа" при будь-якій формі кінцевого контролю. Якісна успішність за всіма спеціальностями була вищою при використанні тестового контролю.

\section{Таблиця 2. Зіставлення резүльтатів якісної успішності (\%) стүдентів різних спеціальностей при проведенні традиційного підходу оцінювання (2013 р.) та тестового контролю з анатомії людини (2014 р.)}

\begin{tabular}{|c|c|c|c|c|c|}
\hline \multirow{2}{*}{ Рік } & \multirow{2}{*}{ Форма навчання } & \multicolumn{4}{|c|}{ Спеціальність } \\
\cline { 3 - 5 } & & \multicolumn{2}{|c|}{ сестринська справа } & \multirow{2}{*}{$\begin{array}{c}\text { акушерська } \\
\text { справа }\end{array}$} & $\begin{array}{c}\text { стоматологія } \\
\text { ортопедична }\end{array}$ \\
\cline { 3 - 6 } & & $\begin{array}{c}\text { денна форма } \\
\text { навчання }\end{array}$ & $\begin{array}{c}\text { вечірня форма } \\
\text { навчаня }\end{array}$ & & \\
\hline \multirow{2}{*}{2013} & державна & $82(91 \%)$ & $29(83 \%)$ & $14(70 \%)$ & $4(80 \%)$ \\
\cline { 2 - 6 } & контрактна & $76(89 \%)$ & $17(68 \%)$ & $7(70 \%)$ & $5(50 \%)$ \\
\hline \multirow{2}{*}{2014} & державна & $87(97 \%)$ & $33(94 \%)$ & $15(94 \%)$ & $5(100 \%)$ \\
\cline { 2 - 5 } & контрактна & $76(95 \%)$ & $19(76 \%)$ & $10(71 \%)$ & $11(73 \%)$ \\
\hline
\end{tabular}

Відмінності якісно успішності студентів зумовлені мотиваційними факторами. Отримані результати збігаються з тим фактом, що за спеціальністю з найвищим рівнем успішності при вступі до коледжу був найвищий конкурс $[1,7]$.

Висновки. Якісна успішність студентів з дисципліни «Анатомія людини» при застосуванні різних форм кінцевого контролю, зберігає співвідношення за різними спеціальностями та формами навчання. Враховуючи те, що показник якісно успішності при ретельно підготовленому та адекватно проведеному пілотному тестовому контролі, демонструє зіставні результати з іншими формами проведення підсумкового контролю, при цьому забезпечуючи високий рівень об'єктивності, ми пропонуємо й подаль- 
ше проведення підсумкового модульного контролю у вигляді тестування. Практичні навички при такій формі кінцевого оцінювання в повному обсязі студент складає на змістовних модулях та наприкінці дисципліни. В подальшому

\section{ЛІТЕРАТУРА}

1. Багрій М. М. Тестовий контроль теоретичних знань у структурі підготовки майбутніх лікарів / М. М. Багрій // Вісник проблем біології і медицини. - 2013. - Вип. 4, T. 1. - С. 64-67.

2. Вища освіта в Україні : навч. посіб. / за ред. В. Г. Кременя, С. М. Николаєнка. - К. : Знання, 2005. $327 \mathrm{c}$.

3. Довгополова Я. В. Впровадження тестової методики в процес навчання у вищих навчальних закладах / Я. В. Довгопопова / / Вісник Харківського національного університету імені В. Н. Каразіна. - 2011. - № 972. - C. 173-178.

4. Замараев В. А. Инновационная система совершенствования непрерывного образовательного процесса по курсу анатомии в вузах ффизической культуры / В. А. Замараев / / Вестник УГТУ-УПИ. Серия «Образование и воспитание. Экономика и управление физической культуры и спорта». Современные проблемы развития ффизической культуры и спорта : сб. науч. статей / под ред. И. В. Брызгалова. - Екатеринбург. 2006. - № 10 (81), Вып. 6, T. 1. - С. 35-37. потрібно розробляти методи контролю знань студентів із базових медичних дисциплін, які відповідають сучасним вимогам об'єктивності та якості.

5. Касярум О. П. Проблеми діагностування й контролю результатів навчання студентів / О. П. Касярум, Н. В. Касярум / / Вісник Черкаського університету. 2010. - Вип. 181. - С. 145-148.

6. Кулагин В. П. Информатизация образования: направления, средства, технологии : пособие [для системы повышения квалификации] / [В. П. Кулагин, Г. А. Краснова, Б. Б. Овезов и др.]. - М. : МЭИ, 2004. $-868 c$.

7. Мистецтво бути викладачем : практ. посіб. / А. Брінклі, Б. Десантс, М. Флемм [та ін.] ; за ред. О. І. Сидоренка. - К. : Навчально-методичний центр «Консорціум із удосконалення менеджмент-освіти в Україніз, 2003. - 144 с.

8. Маладика Л. Тестовий контроль професійних знань у структурі підготовки майбутніх фахівців МНС України / Л. Маладика / / Наукові записки. Серія: Педагогіка. 2009. - № 3. - C. 92-96.

9. Щевелева Г. М. Диапностическое тестирование предметных знаний первокурсников / Г. М. Щевелева // Педагогика. - 2001. - № 7. - С. 53-58. 